\title{
Nahr al-Bared crisis and local responses of aid: a focus on needs assessment during emergencies
}

Lamia Moghnieh

\begin{abstract}
This study describes the process and dynamics of aid during the Nahr al-Bared crisis in 2007. It seeks to explore how previous experiences of relief were capitalized on and used as part of routinized relief procedure in 2007. Based on several interviews conducted, the study provides a general description of the crisis, the problems and challenges faced and the local expertise and skills used during the crisis. The second section focuses specifically on the issue of needs assessment and information consolidation, with the action of sharing playing a vital role in aid. Data sharing was routinized and refined during the conflict to facilitate an efficient and accountable flow of aid and relief for the needed communities. Data consolidation and sharing during emergencies and crises are crucial for ensuring a process of transparency and coordination between different local and global humanitarian organizations.
\end{abstract}

Keywords: displaced Palestinians, Nahr El-Bared War, Palestinian Refugee Camps in Lebanon, refugees, Emergency relief

To cite this paper: Lamia Moghnieh, "Nahr al-Bared crisis and local responses of aid: a focus on needs assessment during emergencies ", Civil Society Knowledge Center, Lebanon Support, October, 2015 . DOI: 10.28943/CSKC.001.30009.

[ONLINE]:

https://civilsociety-centre.org/paper/nahr-al-bared-crisis-and-local-responses-aid-focus-needsassessment-during-emergencies

\section{Introduction}

This case study explores the relief work conducted by different aid workers during the Nahr al-Bared conflict in 2007. It aims to identify and understand how and to what extent experiences of relief in war and conflict, especially the July War (2006), informed Nahr al-Bared relief and recovery work. The study is interested in exploring the different ways in which local expertise and experiences acquired during the July War and other conflicts were used in the Nahr al-Bared conflict, and the types of aid that these community workers provided. For this case study, several interviews were conducted with individuals who worked on providing aid and relief during Nahr al-Bared crisis, and by building on Lebanon Support's extensive archive of the period.

The Nahr al-Bared clashes took place between May 20th and early September 2007, where the Lebanese Armed Forces (LAF) battled Fatah al-Islam militants residing in Nahr al-Bared Palestinian refugee camp1. These three months of combat led to the destruction of the refugee camp, officially hosting more than 31,000 Palestinians $\underline{2}$ Internal displacement, reconstruction and rebuilding of the 
camp became urgent humanitarian issues that required assistance. A plethora of funds, programs and organizations poured into the camp for emergency assistance $\underline{3}$.

This case study seeks to provide a short overview of the forms of aid organized in response to the Nahr al-Bared conflict, with a special focus on information sharing and needs assessment during crisis. Four interviews were conducted with local aid workers from different backgrounds who provided relief at the time of the crisis: one working in an INGO, one managing a local community-based organization, and two community workers from Lebanon Support. The interviewees were selected based on the various experiences they might have had during Nahr al-Bared, enriching the study.

Based on the interviews, the first section of this case study will provide a description of the crisis, an overview of the aid provided, the problems and challenges faced, as well as the type of expertise and aid that were transferred from the July War or re-developed and sculpted further during Nahr al-Bared combats. The second section will focus on needs assessment skills and knowledge sharing expertise developed and acquired during the Nahr al-Bared crisis, and how it influenced the coordination, flow and transparency of aid. It will focus on: a) the way aid communities' needs were captured and b) the ways in which part experience and expertise were relied on to provide this aid. The third section will provide recommendations and best practices.

\section{The Naher El Bared crisis: local expertise and skills revisited and developed}

All the interviewed aid workers agreed that the Nahr al-Bared combats produced a great and difficult crisis to manage and handle. The destruction of the whole camp led to a massive and instant displacement of Palestinian refugees and Lebanese residing in the camp to the neighboring Baddawi refugee camp. The scale of the needs was enormous since most of the displaced did not take many belongings with them, thinking that they were soon to return to the campㄴ. Additionally, the impact of the conflict produced tension and unrest between the Lebanese and the Palestinians, where the stereotyping of Palestinians as Islamist terrorists also had an influence on the crisis itself, and on the aid provided $\underline{5}$. Soon, the scale and nature of the crisis enabled funds from donors to pour in, as many INGOs were still established in Lebanon since the 2006 July War. These organizations soon directed their work from post-conflict developmental work into emergency developmental work. Additionally, organizations with established relationships with the community began a process of facilitation on the ground, providing relief and aid consisting of food and non-food items and psychosocial support interventions $\underline{6}$. While most organizations focused on aiding the displaced communities and sometimes their host families, in Baddawi camp, some sought to send aid and relief to families who in the beginning remained in the Nahr al-Bared camp before it was completely destroyed. Later as families fled the camp, aid followed the displaced and was transferred to these populations. $\underline{7}$

Some INGOs working in the Palestinian camps before the conflict, directly shifted funds and programs to service the aid communities that were now displaced. They benefited from the relationships they already had established in the camp to set a fast emergency response:

"In the beginning there were the local organizations who were already there and established at the Beddawi Camp. World Vision is an international organization, but it was already working in the camps so this helps. We did not need to do partnerships on the sport. We already had the staff, we already 
had our partners, we knew the context and needs (of the camps) and our programs were already ongoing (...). I was working in a psychosocial program, I asked the donor to transfer this fund to make this program into a relief, he approved and we started right away."을

Problems of coordination, competition and allocation of resources soon emerged between INGOs and local organizations, as well as between local groups themselves. For example, many INGOs refused to coordinate and work with Palestinian organizations and instead allocated funds for Lebanese NGOs to dispense and manage the relief as they pleased. Moreover, many coordination meetings took place and subcommittees were established to represent the camp and coordinate aid. However, many organizations arrived without any context of the camp culture and politics and so hired local staff to provide the same services already provided by local organizations $\underline{9}$. Duplication of work then also became a challenge, as identifying the needs and, more importantly, consolidating all the data collected became a crucial skill to facilitate emergency response and make it transparent and accountable in emergency situations. As a result, relief distribution became very sensitive, first because the host community was itself an aid community $\underline{10}$, second because relief distribution was implemented randomly and not based on identified families and individuals in need11.

Prior experiences in relief work, especially during the July war and the 1996 Grapes of Wrath Operation, were used in various ways by the community workers who were engaged in aid and relief prior to the Nahr al-Bared crisis. These community workers' types of expertise varied depending on the institutional and organizational structure she/he belonged to. For example, psychosocial support and interventions were mentioned as one of the main expertise gained during the July War and as a result became much more developed and institutionalized in Nahr al-Bared12. Additionally, knowledge sharing via creating databases and various platforms, where aid communities' needs are captured, consolidated and employed to assess flow of aid, coordination and accountability of organizations, was also a skill acquired during the war and found to be highly crucial for understanding emergencies and crises 13 . The process of hosting the displaced community and providing immediate relief also became more routinized and efficient in 2007. It evolved into a specific methodized and organized skill as aid workers had greater experience from similar humanitarian crises in 1996, 2006, and then 2007. The next section will provide a special focus on the experience of several local community workers and activists in building a community-informed database of needs and crisis information in the July war and during Nahr al-Bared crisis.

\section{Needs assessments and building a procedure for aid response from the July War to Nahr el- Bared}

During the July War, one of Samidoun's units worked on documenting the needs of the displaced communities on various levels 14 . Information on the aid communities and the evolving nature and scale of the conflict was collected and consolidated daily in shelter schools 15 . This database was made public and was shared with different aid organizations during and after the war. The media unit played a role in fundraising for Samidoun, in mobilizing an international solidarity campaign with Lebanon from different allies, friends and groups, and also in compiling, assessing and documenting the shifting needs on the ground16. A primary assessment of needs was conducted on different topics that ranged from health, mental health, different vulnerabilities etc. 
After the ceasefire in August 2006, one of the initiatives undertaken was an initial assessment of South Lebanon that covered around 25 villages on the first day 17 . The assessment was based on a narrative assessment method, where the different teams would collect information about the same theme from at least three different sources, in order to maintain the integrity, accuracy and thickness of the information provided. This is especially important to note as access to information is always hindered in times of emergency18. The narrative method of assessment also served to provide as much information as possible about the postwar situation, collective and individual needs, as well as needs across villages and whether they differed, taking into consideration the types of solutions suggested by local communities themselves to fulfill these needs $\underline{19}$. This initial assessment played a role in coordinating and shaping international and local relief efforts to where they were most needed $\underline{20}$.

The skills of needs assessment and data collection acquired during the July war were adopted again during the Nahr al-Bared crisis, where a similar gap in information emerged. Knowing what communities needed, whether they were located in or outside the camp, and whether they had access to relief became crucial points of information for organizing an efficient response to the evolving emergency 21. Community aid workers provided a platform for all this information in order to benefit relief workers.Specifically, the platform was an information system that could guide and inform programs, policies and funds, to ensure coordination between different organizations 22 . This platform first worked as a mass database recording the needs collected from different sections of aid communities. It also worked to document and assess these needs and the ways to satisfy them. Moreover, the platform worked as a facilitator for coordination, since it published efficient and transparent flows of relief and of funds, providing a template for accountability for the organizations working in relief vis-à-vis the communities they service and the donors. Besides information about the community's needs, the platform also included information about the organizations themselves, the types of services, aid and relief they provided and their process of aid distribution. Analyzing the evolving nature of community needs along with the process of relief distribution facilitated an assessment process for organizations' work, as well as coordination during emergency.

Additionally, the platform functioned as a public information sharing database that was not just able to document the unfolding dynamics of the crisis in the present, but could also be used to predict and assess the outbreak of future needs, crisis and challenges of aid. As such, it worked as a prognosis platform that has influence on the post-conflict process of reconstruction. Thus, the platform served as a body of information that could be analyzed in order to produce relevant developmental programs based on the information gathered by different sources of community workers and the communities themselves $\underline{2}$. The platform therefore facilitated the relief and aid management, in terms of providing a transparent process for fund allocation and relief distribution $\underline{24}$.

The procedure for needs collection during the Nahr al-Bared crisis, as described by community workers from Lebanon Support went as following: the collection of data became more community based during the Nahr al-Bared crisis, and participatory needs assessment were conducted where community members were trained on identifying their own needs 25 . The camp was divided into zones and community workers would do assessments on a daily basis on different topics (education, health, women etc.) while also collecting data on what had been distributed so far, and whether aid communities had access to relief and if that relief satisfied their needs. Around 60 focus groups were also conducted based on 16 different topics, to produce as much specific data as possible $\underline{26}$. The focus 
covered various communities and topics like health and psychological health of women, children and people with special needs. Apart from the needs assessments, data was also collected on the relief distributed by organizations, as well as their own priority services and programs provided:

"Every month we did around 60 focus groups around 16 different topics[...]three with disabled groups in the Baddawi camp to focus on their needs in specific ways, the challenges they faced; a focus group on the way distribution of relief was being made, to make alternative plans for distribution in order to prevent duplication and error in information collection. We also focused on the women since they have different needs, especially during emergency. The focus group served to extract [women's] own needs. The mapping of the needs won't necessarily provide you with a complete description of the situation but at least [account] for $70 \%$. This [information collection] benefited all the organizations [in] the group. We also focused on children, on psychosocial support, we tried to cover everything. On the other hand, we did a study on which organizations focus on priorities. We had a staff that went every day and noted what each aid organization has distributed and published it on the website." 27

This helped understand the process of relief and whether there was duplication in aid228. The public data about the needs and the organizations provided a process of transparency and accountability in how the funds were dispersed and whether the goals of the organizations were met. The more accurate and clear the information was, the easier and more efficient it was to provide relief 29.

\section{Lessons learned}

As this case study shows, experiences acquired during previous wars and conflicts by local community aid workers working with INGOs and local organizations have been further developed and adopted in succeeding conflicts like in Nahr al-Bared. This case study focused on the experience of needs assessment and information consolidation and sharing that emerged out of the experience of several activists in Samidoun, then became routinized and institutionalized as part of the work of relief and of local organizations in Lebanon. The capitalization on earlier conflicts and war was not just on the level of expertise, but also on the level of a complex reading and understanding of crisis management and of the politics and dynamics of global and local interventions, policies and funds during emergencies $\underline{30}$.

Additionally, the importance of consolidated information about the crisis and its impact emerges and becomes crucial during emergencies. The vision was to consolidate and converge different types of data into one platform that could be accessed as an early warning system, as a prognosis for future crises and an indicator for recovery and not just to understand present crises $\underline{31}$. Interviews revealed that the gap of information detected during Nahr el-Bared crisis, but also during the July war, led to duplication of relief in certain cases, and an inefficient distribution of relief. The platform established and refined by the community workers during Nahr el-Bared crisis not only served to minimize these problems, but also enforced a process of coordination between organizations based on the types of services they offered, and the needs they could service in emergency. The presence of a platform that can describe and analyze unfolding needs in emergencies facilitates the transparent management of aid, and communities' access to it.

A continuous bottom-up building of data around aid communities and organizations' relief work in postconflict sites can facilitate and enable an efficient and rapid response to crises $\underline{32}$. It also enables a 
clearer platform for local coordination between different actors involved in giving and receiving aid.

\section{Conclusion}

Facing a new and difficult emergency in 2007 after the July War, information collection, consolidation and assessment on the needs of the communities and the dynamics of aid distribution were used again based on the July war experience, in a more routinized procedure that served to facilitate the management of aid in an efficient and productive way. Skills like the information platform provided and designed by Lebanon Support community workers served to provide detailed information for the emergency at hand and the role of aid organizations in it. The database was also able to provide a reliable prognosis for suitable programs in the post-conflict phase. This study provided a description of this skill in the context of the Nahr al-Bared crisis in 2007.

\section{Bibliography}

Bassem Chit, "Samidoun Relief Center", internal report, 2007

Lamia Moghnieh, "Local forms of relief during the July War in 2006 and international humanitarian interventions: implications on community preparedness for war and conflict", Civil Society Knowledge Centre, Lebanon Support, June 5th, 2015, available

at: https://civilsociety-centre.org/paper/local-forms-relief-during-july-war-2006-and-internationalhumanitarian-interventions [last accessed on July 4th, 2015].

Lebanon Support, The Nahr-El Bared War https://civilsociety-centre.org/dossier/nahr-el-bared-war[last accessed, October 5th 2015]

Michael Bluhm, A look back at the conflict in Nahr al-Bared, http://www.dailystar.com.lb/News/Lebanon-News/2007/Dec-27/48358-a-look-back-on-theconflict-in-Naher-al-bared.ashx,2007 [last accessed Octiber 5th 2015]

- 1 . http://www.dailystar.com.lb/News/Lebanon-News/2007/Dec-27/48358-a-look-back-on-theconflict-in-Naher-al-bared.ashx

- 2. Around 168 LAF soldier and more than 22 militants and more than 20 civilians were reportedly killed during the war http://www.dailystar.com.lb/News/Lebanon-News/2007/Dec-27/48358-a-look-back-on-theconflict-in-Naher-al-bared.ashx.

- $\underline{3}$. For more on the Naher al Bared war crisis, please refer to this dossier prepared by Lebanon Support: https://civilsociety-centre.org/dossier/Naher-el-bared-war

- 4. Interview with Leila el-Ali, Najdeh Association, September 2015

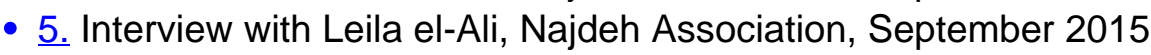




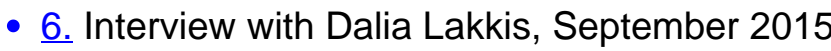

- 7. Interview with Leila el-Ali, Najdeh Association, September 2015

- 8. Interview with Dalia Lakkis, September 2015

- 9. Interview with Leila el-Ali, Najdeh Association, September 2015

- 10. Interview with Dalia Lakkis, September 2015

- 11. Interview with Walid Taha, September 2015

- 12. Interview with Dalia Lakkis, September 2015; Interview with Leila el-Ali, September 2015

- 13. Interview with Leila el-Ali, September 2015

- 14. Samidoun has been the subject of an in-depth case study published by Lebanon Support. See Lamia Moghnieh, "Local forms of relief during the July War in 2006 and international humanitarian interventions: implications on community preparedness for war and conflict", Civil Society Knowledge Centre, Lebanon Support, June 5th, 2015, available

at: https://civilsociety-centre.org/paper/local-forms-relief-during-july-war-2006-and-internationalhumanitarian-interventions [last accessed on July 4th, 2015].

- 15. Interview with Bernadette Daou, April 2013; Interview with Ghassan Makarem, February 2015

- 16. Interview with Ghassan Makarem, February 2015

- 17. Bassem Chit, "Samidoun Relief Center", internal report, 2007

- 18. Bassem Chit, "Samidoun Relief Center", internal report, 2007

- 19. Bassem Chit, "Samidoun Relief Center", internal report, 2007

- 20. Bassem Chit, "Samidoun Relief Center", internal report, 2007; Interview with Ghassan Makarem, February 2015

- 21. Interview with Ghassan Makarem, February 2015; Interview with Walid Taha, September 2015

- 22. Interview with Walid Taha, September 2015, Interview with Ghassan Makarem, February 2015; Interview with Hussein Yackoub, September 2015

- 23. Interview with Hussein Yackoub, Septebemr 2015

- 24. Interview with Walid Taha, September 2015

- 25. Interview with Ghassan Makarem, February 2015

- 26. Interview with Walid Taha, September 2015

- 27. Interview with Walid Taha, September 2015

- 28. Interview with Walid Taha, September 2015; Interview with Hussein Yackoub, September 2015

- 29. Interview with Walid Taha; Interview with Hussein Yackoub, September 2015; Interview with Ghassan Makarem, February 2015

- 30. Interview with Hussein Yackoub, September 2015

- 31. Interview with Ghassan Makarem, February 2015

- 32. Interview with Walid Taha, September 2015; Interview with Ghassan Makarem, January 2015 